\title{
Pengaruh Tulangan Tekan Terhadap Beban-Defleksi, Kekakuan, Daktilitas, dan Pola Retak pada Balok Beton Bertulang Dengan Software ATENA 3D
}

\author{
Ahmad Zaki*1, Rafi Zakiy ${ }^{2}$ \\ ${ }^{1,2}$ Program Studi Teknik Sipil, Fakultas Teknik, Universitas Muhammadiyah Yogyakarta, Bantul, 55183 \\ Daerah Istimewa Yogyakarta, Indonesia \\ e-mail: ${ }^{1}$ ahmad.zaki@umy.ac.id, ${ }^{2}$ rafizakiy@gmail.com
}

Received 18 May 2021; Reviewed 16 July 2021; Accepted 06 December 2021

Journal Homepage: http://jurnal.borneo.ac.id/index.php/borneoengineering

\begin{abstract}
Steel reinforcement was an important material in the reinforced concrete beams. In the design, the steel reinforcement must be able to assume the forces that are accepted both vertically, horizontally, and laterally. The reinforcement in concrete was divided into two, namely compressive reinforcement and tensile reinforcement. Tensile reinforcement had a role in strengthening the beam in accepting bending loads. Meanwhile, compressive reinforcement plays a role in holding the tensile load that occurs in the beam. Along with the development of technology, reinforced concrete plans are using the finite element method in an application. The purpose of this research is to determine the effect of the addition of compression reinforcement on reinforced concrete beams using ATENA 3D software. From the analysis results, it obtained the highest ductility value of 21,6969 while the smallest ductility value of 1,1796. The highest stiffness value of 145,6491 while the smallest stiffness values are found in a value of 6,4843. These data show that the addition of compressive reinforcement to the reinforced concrete beam reduces the ductility and increases the stiffness.
\end{abstract}

Keywords: RC beams, finite element method, ATENA 3D, ductility, stiffness

\begin{abstract}
Abstrak
Tulangan (baja) adalah material yang penting dalam struktur balok beton bertulang. Dalam perencanaan, tulangan harus dapat memikul gaya-gaya yang diterima baik secara vertikal, horizontal, maupun lateral. Penulangan dalam beton dibagi menjadi dua yaitu tulangan tekan dan tulangan tarik. Tulangan tarik memiliki peranan memperkuat balok dalam menerima beban lentur. Sedangkan tulangan tekan berperan menahan beban tarik yang terjadi pada balok. Seiring dengan berkembangnya teknologi perencanaan penulangan balok dilakukan dengan metode elemen hingga dalam suatu aplikasi. Tujuan dari penelitian ini adalah untuk mengetahui bagaimana pengaruh penambahan tulangan tekan pada balok beton bertulang dengan menggunakan software ATENA 3D. Hasil analisis didapatkan nilai daktilitas terbesar dengan nilai 21,6969 sedangkan nilai daktilitas terkecil dengan nilai 1,1796. Nilai kekakuan terbesar dengan nilai 145,6491 sedangkan untuk nilai kekakuan terkecil dengan nilai 6,4843. Dari data tersebut menunjukkan bahwa penambahan tulangan tekan pada balok beton memperkecil nilai daktilitas dan memperbesar nilai kekakuan.
\end{abstract}

Kata kunci: Balok beton bertulang, metode elemen hingga, ATENA 3D, daktalitas, kekakuan 


\section{Pendahuluan}

Dalam pelaksanaannya beton kerap dipilih sebagai material yang sering digunakan di lapangan. Beton memiliki sifat non-linier karena material penyusunnya yang heterogen (Sukarno and Sulistyo, 2015). Beton merupakan material yang digunakan dalam pembuatan struktur balok bertulang. Balok bertulang harus direncanakan dengan baik untuk menahan beban yang bekerja pada arah tegak lurus sumbunya (Bastian, 2017). Seiring berkembangnya teknologi perencanaan, desain balok beton bertulang dapat dilakukan melalui perangkat lunak. Pemodelan balok bertulang dengan perangkat lunak dilakukan dengan mengevaluasi nilai hubungan beban dan defleksi pada balok beton bertulang. Banyak penelitian aplikatif yang menggunakan metode elemen hingga untuk analisis sifat mekanis balok beton bertulang. Hal ini dilakukan disebabkan balok beton bertulang sulit diprediksi, terkadang terjadi keadaan runtuh yang disebabkan oleh gaya yang berbeda dengan keruntuhan akibat lentur (Nawy, 1998).

Dalam bidang rekayasa, metode elemen hingga digunakan untuk analisa berbagai simulasi atau pemodelan dengan menggunakan perangkat lunak. Penggunaan metode elemen hingga juga menjadi basis dari perangkat lunak yang digunakan sebagai pendekatan terhadap keadaan non-linier struktur balok beton bertulang (Darma and Paryati, 2019). Metode elemen hingga memiliki konsep membuat elemen-elemen kecil hasil dari pembagian bagian-bagian struktur yang kemudian dihubungkan oleh titik-titik dari elemen-elemen tersebut, permukaan atau garis tertentu yang dinamakan dengan dekritisasi (Stefany and Supartono, 2019). Dalam penyelesaian masalah, metode elemen hingga memiliki 2 metode, yaitu: pertama, metode elemen hingga menyelesaikan masalah dengan suatu persamaan kemudian dianalisa secara keseluruhan hingga muncul penyelesaian, dan kedua, metode elemen hingga akan mencari pendekatan yang tidak diketahui pada titik tertentu dalam sistem kontinyu terhadap nilai aktual dari hasil penyelesaian.

Banyak aplikasi atau perangkat lunak metode elemen hingga yang digunakan untuk simulasi atau pemodelan struktur beton bertulang. Salah satu metode elemen hingga yang sering digunakan pada pemodelan struktur beton bertulang selain ABAQUS adalah ATENA (Cervenka et al., 2002, Sucharda et al., 2014, Fajarianto et al., 2020, Zaki and Nugroho, 2021). ATENA adalah perangkat lunak berbasis elemen hingga, yang secara khusus diciptakan untuk pemodelan beton bertulang. Penelitian ini merupakan pengaplikasian metode elemen hingga dalam perangkat lunak dengan ATENA 3D untuk menganalisis struktur balok beton bertulang. Penelitian ini bertujuan untuk mengkaji pengaruh penambahan tulangan tekan terhadap perilaku mekanis pada balok beton bertulang.

\section{Metode Penelitian}

\subsection{Pemodelan Balok Beton Bertulang}

Pemodelan balok beton bertulang seluruhnya dilakukan dengan program ATENA 3D. Benda uji yang dibuat berjumlah 60 balok beton bertulang dengan variasi dari parameter yaitu panjang bentang, penampang, mutu beton, dan tulangan. Untuk panjang bentang balok yang digunakan adalah balok dengan bentang 2 meter, 3 meter, 3,5 meter, dan 4 meter. Mutu beton yang digunakan adalah beton mutu $20 \mathrm{MPa}$, $30 \mathrm{MPa}$, dan $40 \mathrm{MPa}$. Sedangkan untuk penggunaan tulangan menggunakan tulangan D18 dan D20. Sengkang yang digunakan yaitu tulangan D12. Pemodelan Balok dalam penelitian ini disingkat dengan kode PB yang kemudian dimodelkan dalam program ATENA 3D seperti yang disajikan pada Tabel 1 dan 2. 
Tabel 1. Spesifikasi pemodelan balok beton bertulang tanpa tulangan tekan

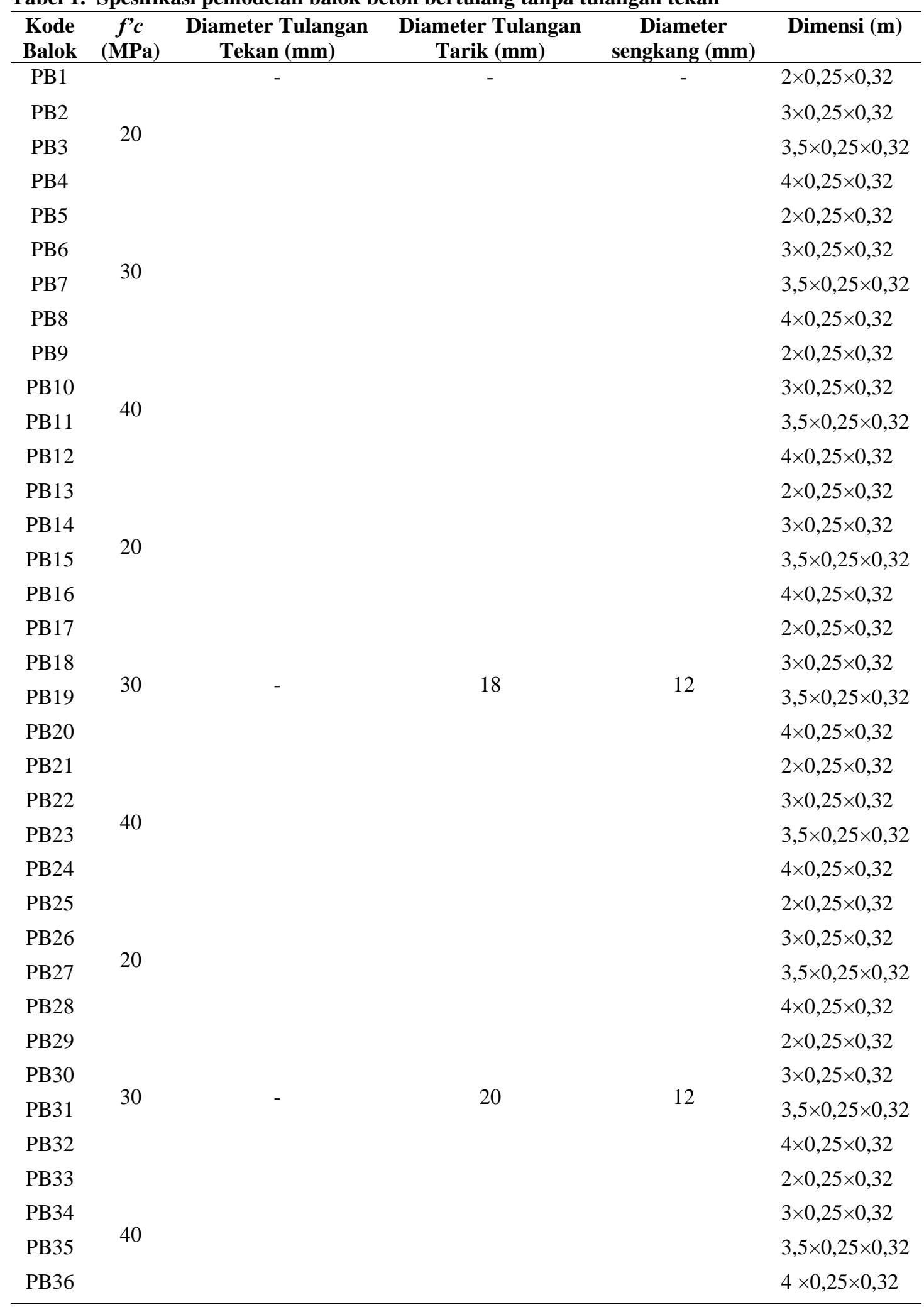


Tabel 2. Spesifikasi pemodelan balok beton bertulang dengan tulangan tekan

\begin{tabular}{|c|c|c|c|c|c|}
\hline $\begin{array}{l}\text { Kode } \\
\text { Balok }\end{array}$ & $\begin{array}{c}f^{\prime} c \\
(\mathbf{M P a})\end{array}$ & $\begin{array}{c}\text { Diameter Tulangan } \\
\text { Tekan }(\mathbf{m m})\end{array}$ & $\begin{array}{c}\text { Diameter Tulangan } \\
\text { Tarik (mm) }\end{array}$ & $\begin{array}{c}\text { Diameter } \\
\text { sengkang }(\mathbf{m m})\end{array}$ & Dimensi (m) \\
\hline PB37 & \multirow{4}{*}{20} & \multirow{11}{*}{ 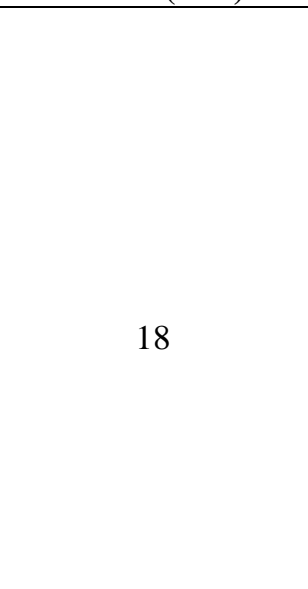 } & \multirow{11}{*}{18} & \multirow{11}{*}{12} & $2 \times 0,25 \times 0,32$ \\
\hline PB38 & & & & & $3 \times 0,25 \times 0,32$ \\
\hline PB39 & & & & & $3,5 \times 0,25 \times 0,32$ \\
\hline PB40 & & & & & $4 \times 0,25 \times 0,32$ \\
\hline PB41 & \multirow{4}{*}{30} & & & & $2 \times 0,25 \times 0,32$ \\
\hline PB42 & & & & & $3 \times 0,25 \times 0,32$ \\
\hline PB43 & & & & & $3,5 \times 0,25 \times 0,32$ \\
\hline PB44 & & & & & $4 \times 0,250,32$ \\
\hline PB45 & \multirow{4}{*}{40} & & & & $2 \times 0,25 \times 0,32$ \\
\hline PB46 & & & & & $3 \times 0,25 \times 0,32$ \\
\hline PB47 & & & & & $3,5 \times 0,25 \times 0,32$ \\
\hline PB48 & & \multirow{13}{*}{20} & \multirow{13}{*}{20} & \multirow{13}{*}{12} & $4 \times 0,25 \times 0,32$ \\
\hline PB49 & \multirow{4}{*}{20} & & & & $2 \times 0,25 \times 0,32$ \\
\hline PB50 & & & & & $3 \times 0,25 \times 0,32$ \\
\hline PB51 & & & & & $3,5 \times 0,25 \times 0,32$ \\
\hline PB52 & & & & & $4 \times 0,25 \times 0,32$ \\
\hline PB53 & & & & & $2 \times 0,25 \times 0,32$ \\
\hline PB54 & & & & & $3 \times 0,25 \times 0,32$ \\
\hline PB55 & 30 & & & & $3,5 \times 0,25 \times 0,32$ \\
\hline PB56 & & & & & $4 \times 0,25 \times 0,32$ \\
\hline PB57 & \multirow{4}{*}{40} & & & & $2 \times 0,25 \times 0,32$ \\
\hline PB58 & & & & & $3 \times 0,25 \times 0,32$ \\
\hline PB59 & & & & & $3,5 \times 0,25 \times 0,32$ \\
\hline PB60 & & & & & $4 \times 0,25 \times 0,32$ \\
\hline
\end{tabular}

\subsection{Tahapan Pemodelan}

Tahapan dalam pemodelan ATENA 3D dibagi menjadi beberapa tahapan sebagai berikut:

1. Input material

Input material adalah tahapan pendefinisian material sesuai dengan data yang telah direncanakan. Material yang dimasukkan ke dalam tahapan ini terdiri dari tulangan tekan, tulangan tarik, beton, dan plat baja.

Tabel 3. Input Data Tulangan

\begin{tabular}{ccccc}
\hline No & Tulangan & Tipe & Modulus Elastisitas (E, MPa) & Tegangan Lelah (бy, MPa) \\
\hline 1 & Tarik & Bilinier & 200.000 & 320 \\
2 & Tekan & Bilinier & 200.000 & 320 \\
3 & Geser & Bilinier & 200.000 & 240 \\
\hline
\end{tabular}




\section{Membuat geometri}

Tahapan ini dimaksudkan untuk memodelkan geometri balok ke dalam program. Untuk setiap balok beton dan pelat baja dimodelkan sebagai Macro-element. Sedangkan untuk tulangan baja pemodelan konfigurasinya digunakan elemen Reinforcement Bars.

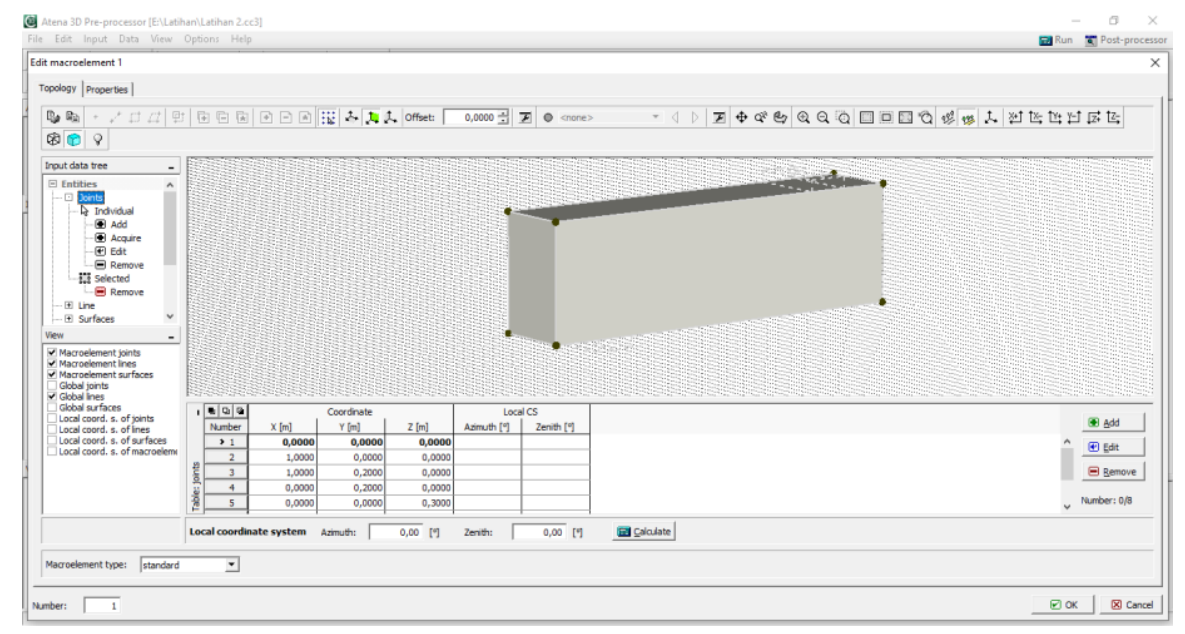

Gambar 1 Geometri Balok pada ATENA 3D

3. Membuat elemen hingga (meshing)

Membuat elemen hingga dimaksudkan untuk membagi elemen balok menjadi lebih kecil dan lebih kompleks untuk dianalisis ketika proses running. Pada pembuatan nilai elemen hingga atau global element size adalah $0,07 \mathrm{~m}$.

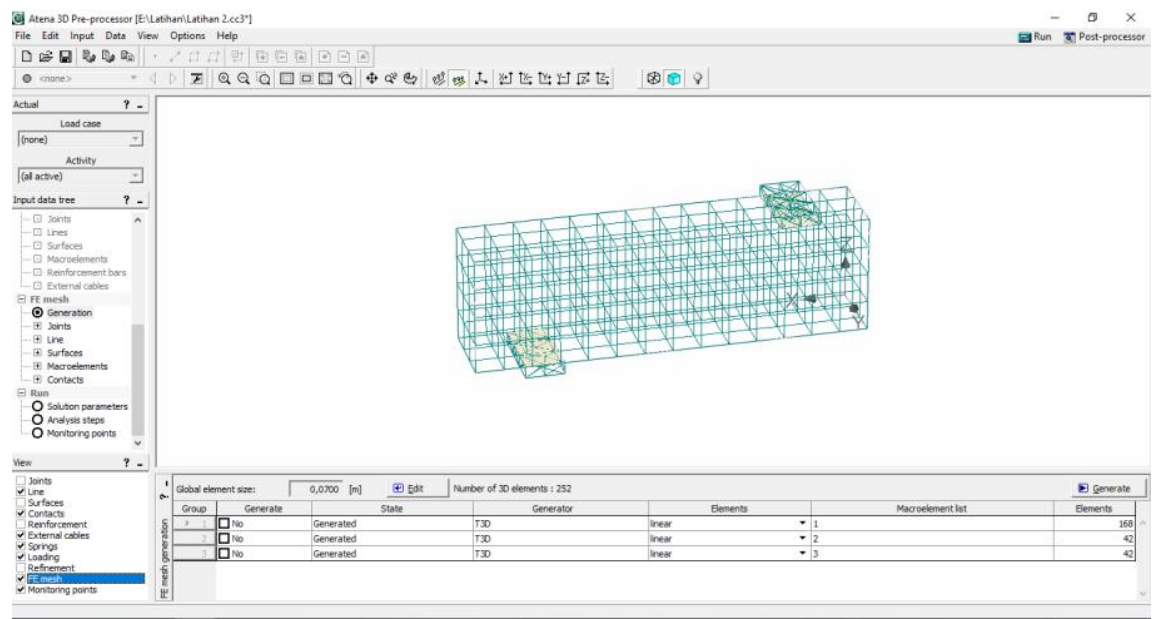

Gambar 2 FE Mesh dengan ATENA 3D

4. Memasukkan support dan beban

Tahap ini dimaksudkan untuk memberikan pembebanan pada pemodelan balok dengan nilai yang telah ditentukan. Proses pembebanan pada program ATENA bersifat kumulatif dari setiap satu yang artinya beban tersebut dijumlahkan dari step sebelumnya.

5. Menentukan parameter solusi 
Tahap ini bertujuan untuk menentukan parameter ketika pemodelan balok mengalami pembebanan pada proses running. Parameter tersebut terdiri dari displacement error multiple, residual error multiple, absolute residual error multiple, dan energi error multiple.

6. Mengatur langkah analisis

Mengatur langkah analisis adalah tahap pengaturan ketelitian data setiap analisis. Pada tahap ini juga dilakukan penentuan jumlah step untuk analisis yang akan dilakukan.

7. Menentukan titik pantau

Tahap ini dimaksudkan untuk mengetahui nilai gaya dan perpindahan akibat beban yang terjadi pada pemodelan balok dengan melakukan pemantauan pada titik yang telah direncanakan.

\section{Running program}

Setelah pemodelan balok selesai maka dilakukan running pada program. Pada proses running mulamula tekan tombol run pada sudut atas kanan layar. Setelah itu tempatkan balok sesuai dengan layer pada ATENA 3D, lalu klik tombol calculate untuk menganalisis sifat mekanis balok yang telah dimodelkan. Grafik akan muncul setelah selesai step analysis. Untuk memunculkan grafik hubungan dan lendutan, grafik harus diatur terlebih dahulu dengan mengatur sumbu $x$ sebagai lendutan dan sumbu y sebagai beban.

\section{Hasil dan Pembahasan}

\subsection{Beban-Defleksi}

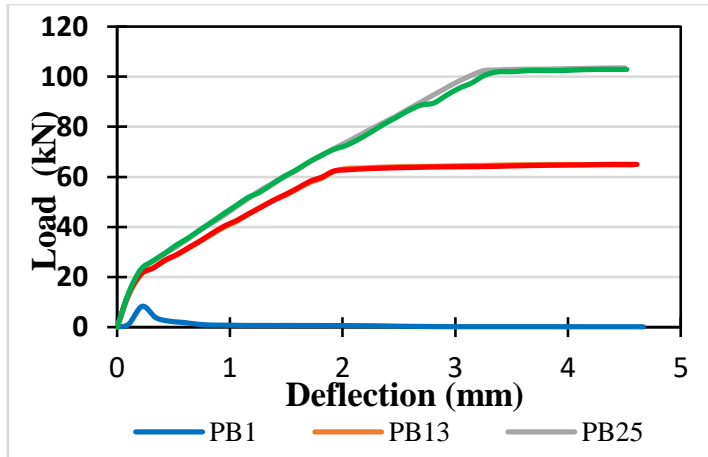

(a)

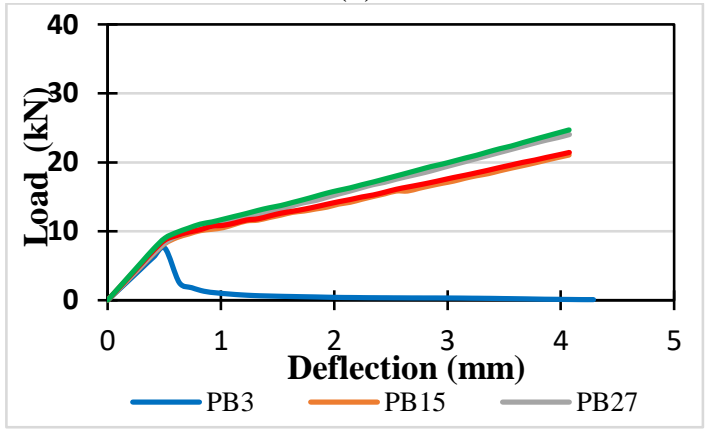

(c)

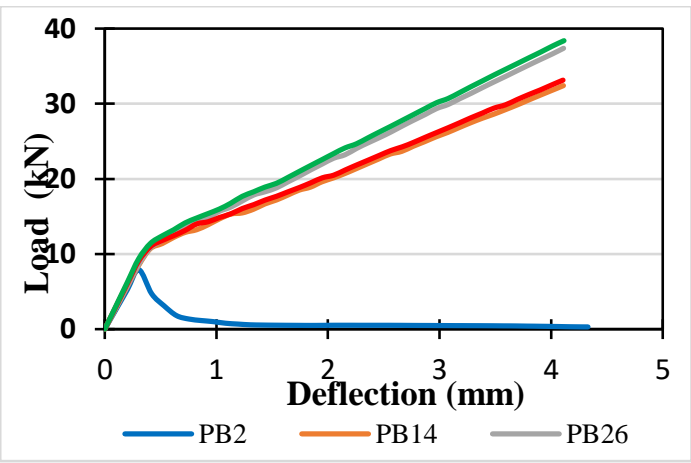

(b)

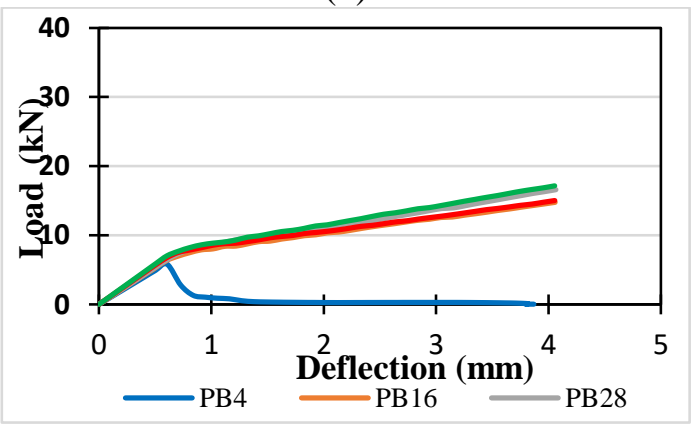

(d)

Gambar 3 Beban-Defleksi Balok mutu 20 MPa (a) bentang 2 m, (b) bentang 3 m, (c) bentang 3,5 m, dan (d) bentang $4 \mathrm{~m}$ 
Gambar 3 menunjukan beban-defleksi balok mutu 20 MPa pada bentang balok $2 \mathrm{~m}, 3 \mathrm{~m}, 3.5 \mathrm{~m}$, dan $4 \mathrm{~m}$. Pada Gambar 3(a)-(d) menunjukan kapasitas kekuatan balok semakin besar dengan bertambahnya tulangan tarik, tulangan tekan, dan tulangan sengkang. Sementara itu, di sisi lain, dengan bertambahnya panjang balok mulai dari bentang $2 \mathrm{~m}, 3 \mathrm{~m}, 3.5 \mathrm{~m}$, sampai $4 \mathrm{~m}$ mengakibatkan kapasitas kekuatan balok semakin kecil. Hal ini menunjukkan bahwa semakin panjang bentang balok maka nilai kekuatan akan semakin kecil (Prayuda et al., 2018, Mansor et al., 2020). Pada Gambar 3(a)-(d), semua balok tanpa tulangan mencapai beban ultimate pada saat balok mengalami retak pertama karena tidak ada tulangan yang bisa menahan gaya tarik yang terjadi karena pembebanan. Pada Gambar 3(a), balok bentang $2 \mathrm{~m}$ dengan adanya tulangan tarik, tulangan tekan, dan tulangan sengkang, balok tersebut mengalami keruntuhan tarik, yaitu balok hancur setelah tulangan tariknya meleleh. Sementara pada Gambar 3(b)-(d), balok bentang 3 m, 3.5 m, dan $4 \mathrm{~m}$ dengan adanya tulangan tarik, tulangan tekan, dan tulangan sengkang, balok mengalami keruntuhan seimbang, yaitu balok hancur bersamaan dengan melelehnya tulangan.

Gambar 4 dan 5 mempunyai perilaku yang hampir sama seperti yang dijelaskan pada pembahasan di atas untuk Gambar 3. Pada Gambar 3-5, dengan bertambahnya mutu beton tidak berpengaruh signifikan pada kapasitas kekuatan dan defleksi pada balok dengan penjang dan properties yang sama.

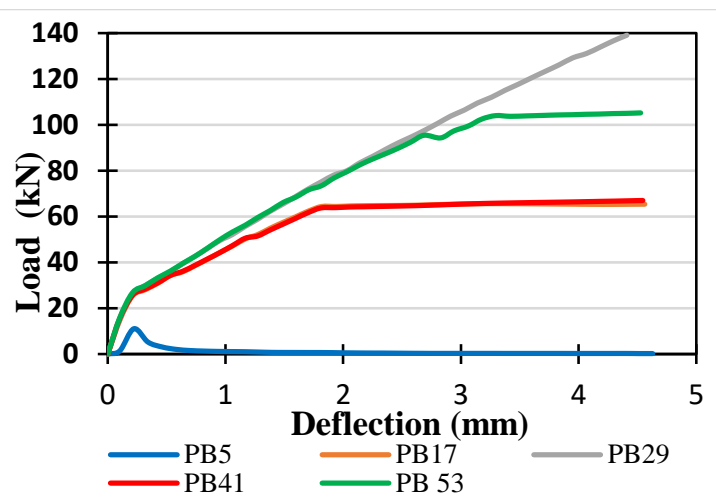

(a)

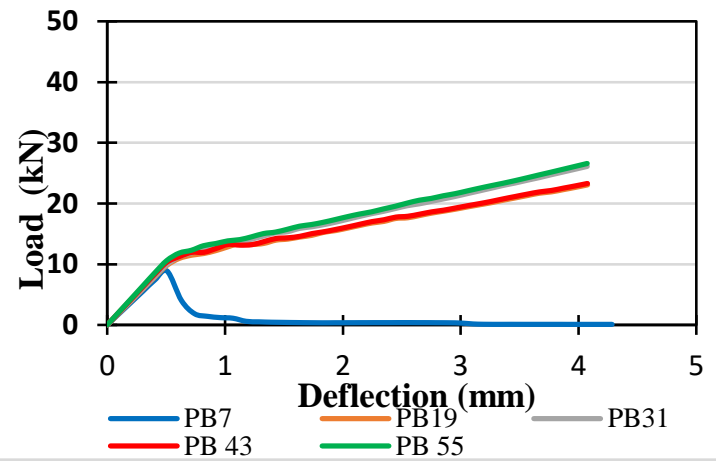

(c)

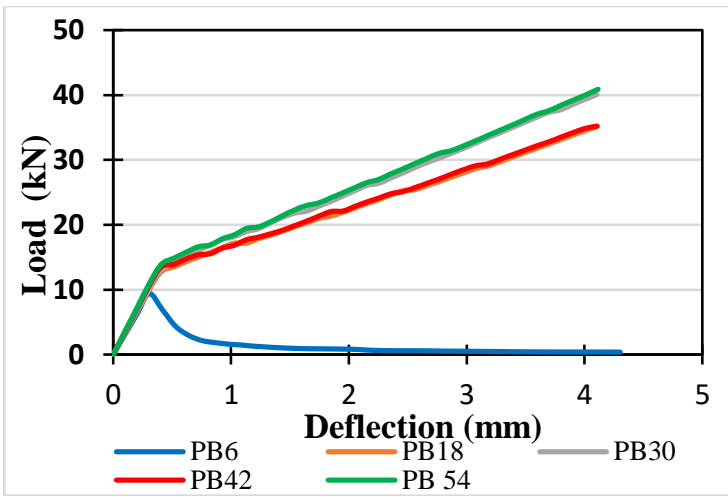

(b)

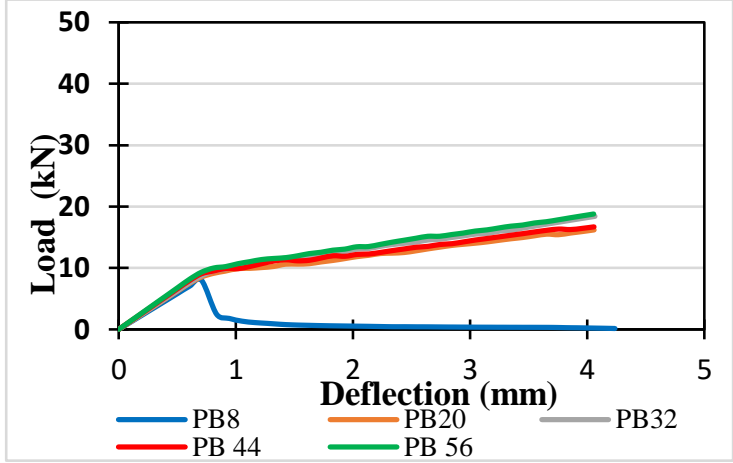

(d)

Gambar 4 Beban-Defleksi Balok mutu 30 MPa (a) bentang 2 m, (b) bentang 3 m, (c) bentang 3,5 m, dan (d) bentang $4 \mathrm{~m}$ 


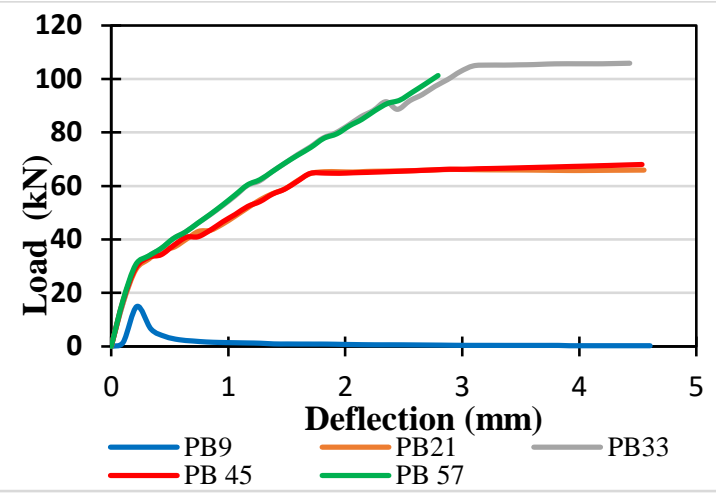

(a)

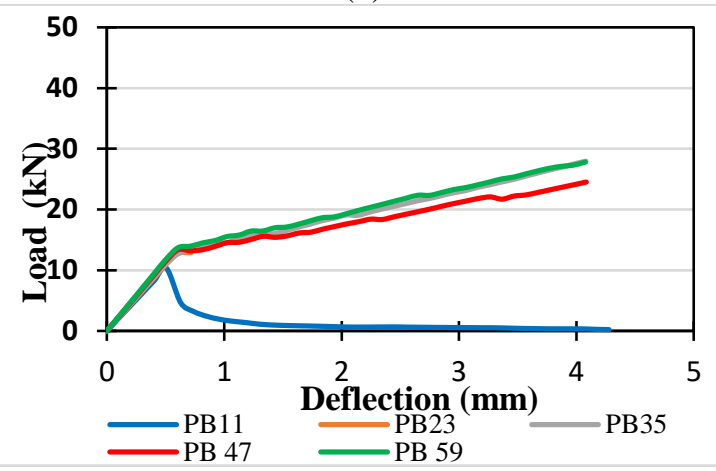

(c)

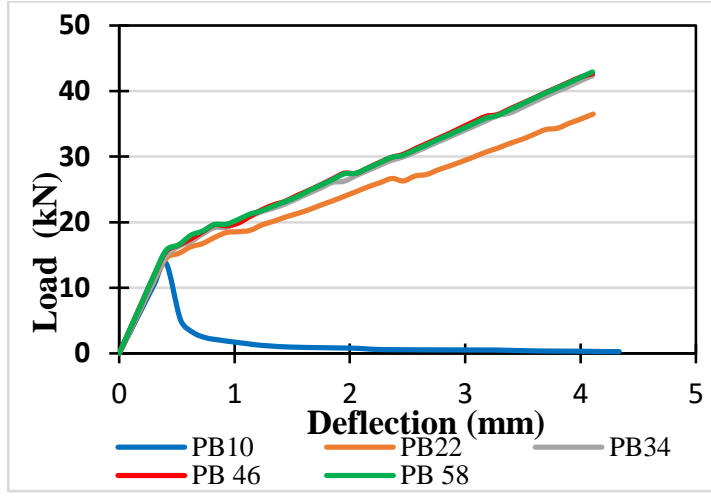

(b)

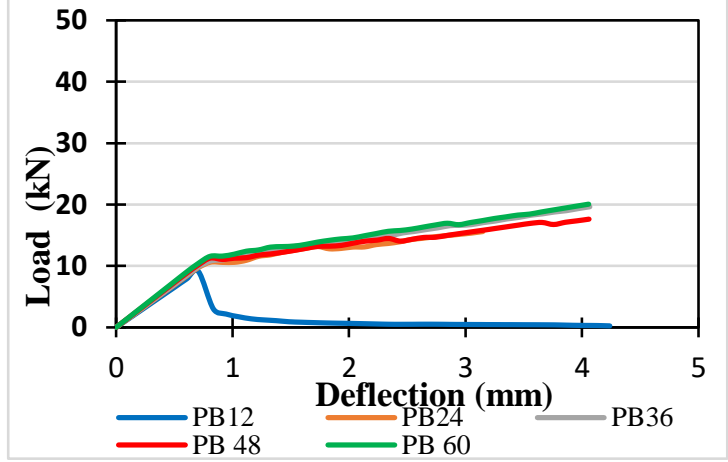

(d)

Gambar 5 Beban-Defleksi Balok mutu 40 MPa (a) bentang 2 m, (b) bentang 3 m, (c) bentang 3,5 $\mathrm{m}$, dan (d) bentang $4 \mathrm{~m}$

\subsection{Kekakuan}

Dari hasil analisa nilai kekakuan dipengaruhi oleh panjang bentang balok, mutu beton, serta tulangan yang digunakan seperti yang digambarkan pada Gambar 6-8. Untuk nilai kekakuan tertinggi terdapat pada PB57 (balok bentang $2 \mathrm{~m}$, mutu 40 MPA dengan tulangan tarik, tekan, dan sengkang) dengan nilai 145,6491 sedangkan untuk nilai kekakuan terkecil terdapat pada PB20 (balok bentang $4 \mathrm{~m}$, mutu $30 \mathrm{MPa}$ dengan tulangan tarik dan sengkang) dengan nilai 6,843. Nilai kekakuan pada balok tanpa tulangan lebih kecil daripada balok dengan tulangan. Hal ini disebabkan penambahan tulangan dapat membuat struktur balok lebih kaku dan memiliki kapasitas beban yang lebih tinggi (Qin et al., 2017). Pada Gambar 6-8, dengan bertambahnya panjang bentang mengakibatkan penurunan kekakuan pada balok bertulang. Di sisi lain, dengan bertambahnya mutu balok mengakibatkan bertambahnya kekakuan pada balok bertulang. Dan juga, dengan penambahan tulangan tekan mengakibatkan kenaikan kekakuan pada balok bertulang.

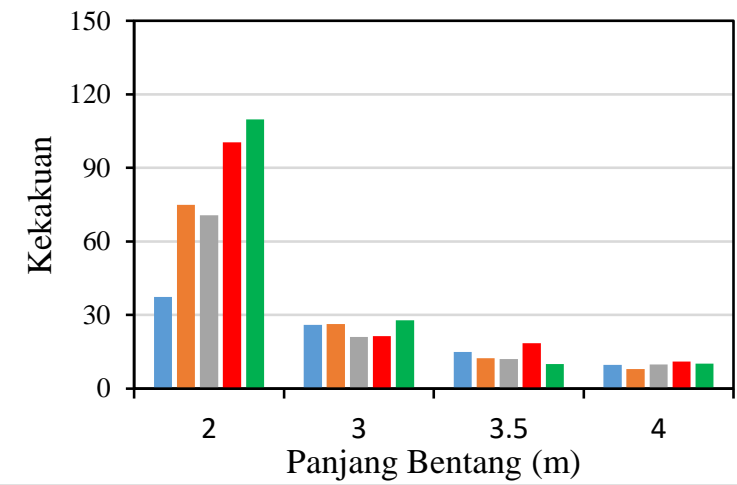

$$
\begin{aligned}
& \text { Balok Tanpa } \\
& \text { Tulangan } \\
& \text { Balok Tulangan } \\
& \text { Tarik D18 } \\
& \text { Balok Tulangan } \\
& \text { Tarik D20 } \\
& \text { Balok Tul. Tarik dan } \\
& \text { Tul. Tekan D18 } \\
& \text { Balok Tul. Tarik dan } \\
& \text { Tul. Tekan D20 }
\end{aligned}
$$

Gambar 6 Hasil Kekakuan pemodelan balok mutu 20 MPa 


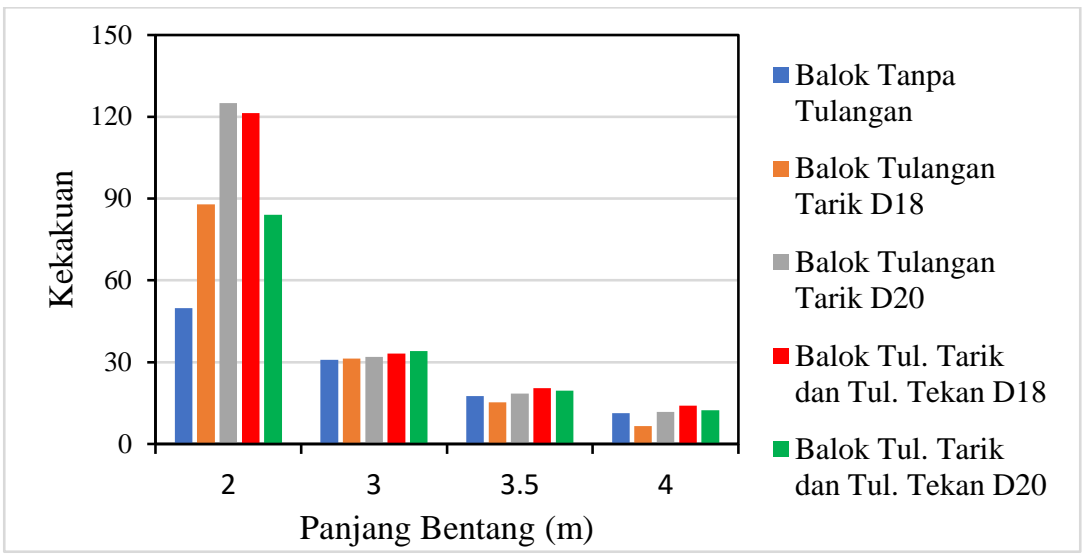

Gambar 7 Hasil Kekakuan pemodelan balok mutu 30 MPa

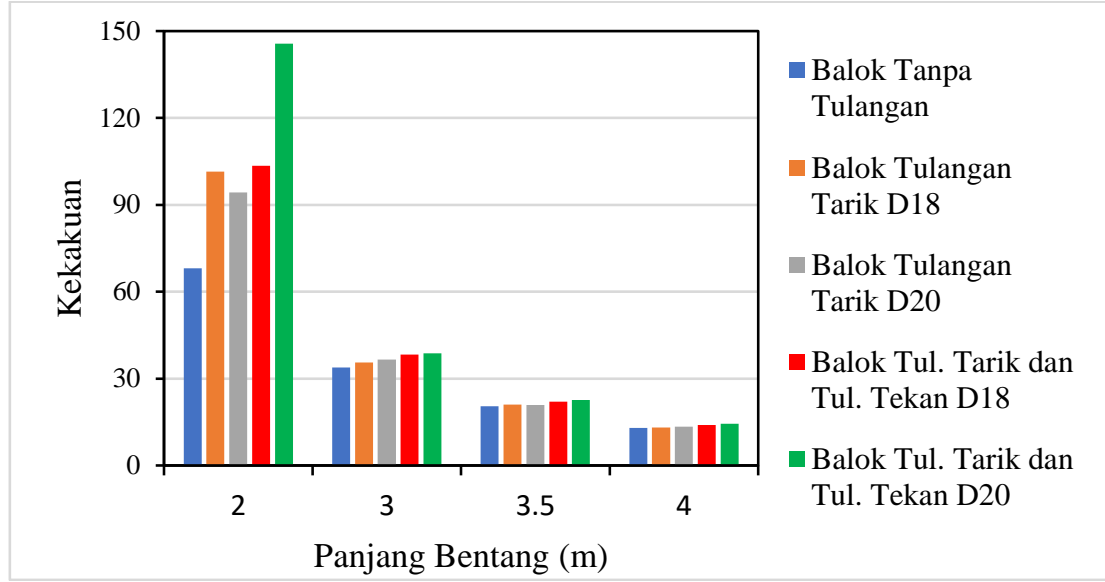

Gambar 8 Hasil Kekakuan pemodelan balok mutu 40 MPa

\subsection{Daktilitas}

Dari hasil analisa nilai daktilitas dipengaruhi oleh panjang bentang balok, mutu beton, serta tulangan yang digunakan seperti yang diperlihatkan pada Gambar 9-11. Dari hasil analisa didapat nilai daktilitas terbesar pada PB49 (balok bentang 2 m, mutu 20 MPa dengan tulangan tarik, tekan, dan sengkang) dengan nilai 21,6969 sedangkan untuk nilai daktilitas terkecil terdapat pada PB23 (bentang $3.5 \mathrm{~m}$, mutu $40 \mathrm{MPa}$ dengan tulangan tarik dan Sengkang) dengandengan nilai 1,1796. Dari hasil dapat disimpulkan bahwasanya nilai daktilitas pada pemodelan terpengaruh oleh panjang bentang penambahan tulangan. Pada balok dengan penambahan tulangan memiliki pengaruh pada nilai daktilitas balok (Qin et al., 2017, Renić and Kišiček, 2021). Dari Gambar 9-11, dengan bertambahnya panjang bentang mengakibatkan penurunan daktilitas pada balok bertulang. Di sisi lain, dengan bertambahnya mutu balok mengakibatkan berkurang daktilitas pada balok bertulang. Dan juga, dengan penambahan tulangan tekan mengakibatkan penurunan daktilitas pada balok bertulang. 


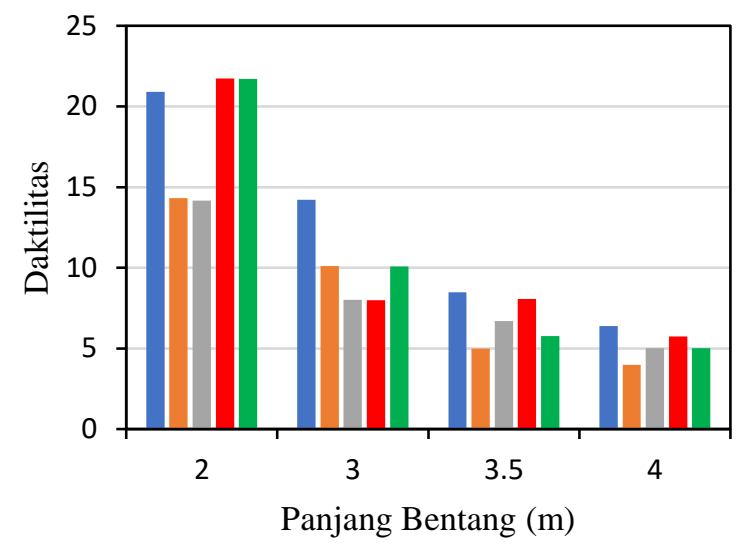
Balok Tanpa
Tulangan
Balok Tulangan
Tarik D18
Balok Tulangan
Tarik D20
- Balok Tul. Tarik dan Tul. Tekan D18
- Balok Tul. Tarik dan Tul. Tekan D20

Gambar 9 Hasil Daktalitas pemodelan balok mutu 20 MPa

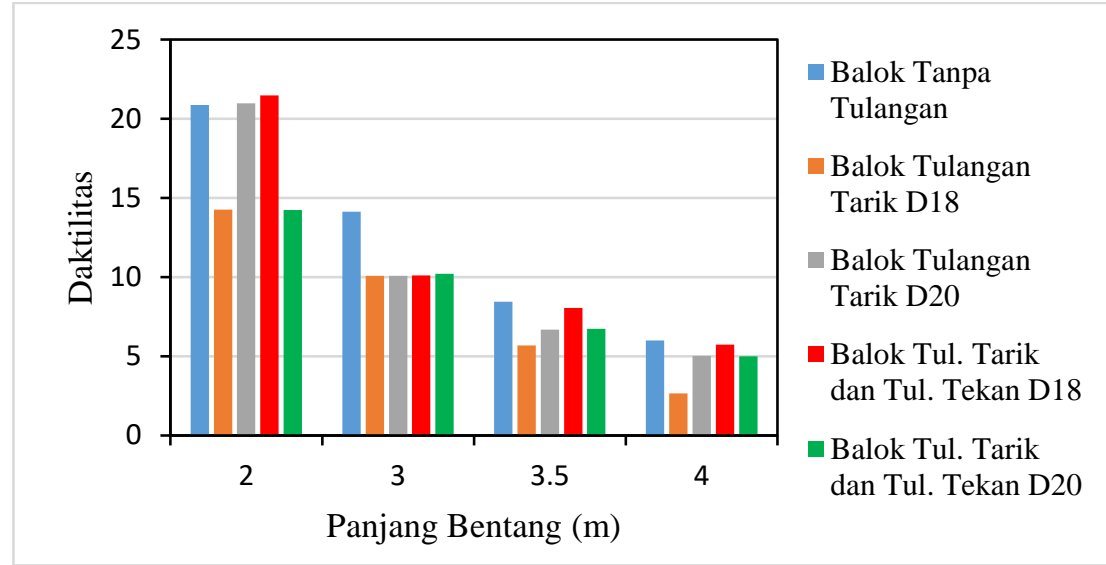

Gambar 11 Hasil Daktalitas pemodelan balok mutu 30 MPa

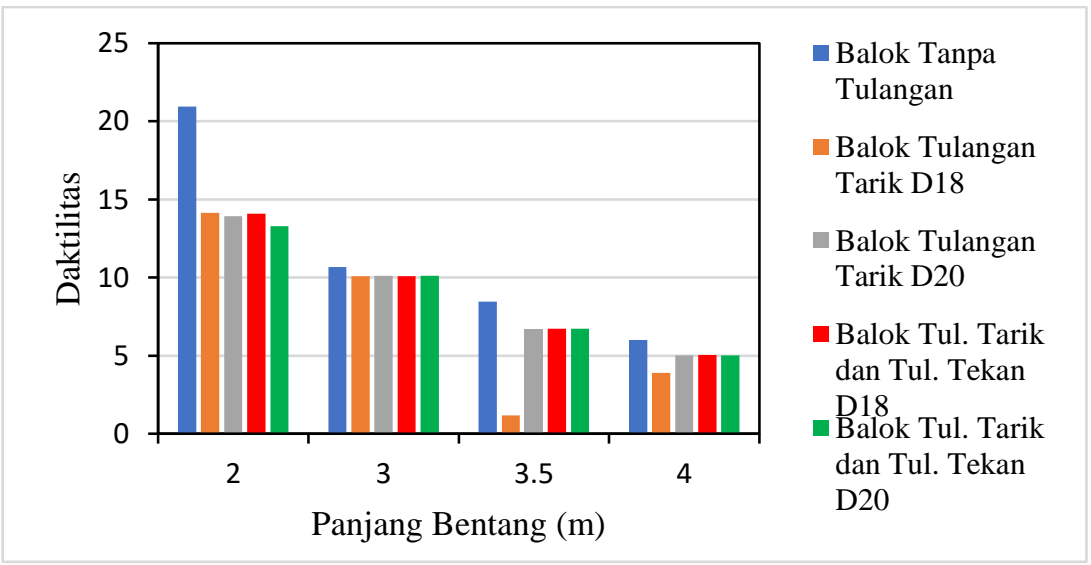

Gambar 12 Hasil Daktalitas pemodelan balok mutu 40 MPa

\subsection{Pola keretakan balok}

Pola retak pada balok tanpa tulangan terbagi menjadi dua yaitu pola retak pada kondisi awal dan pola retak pada kondisi beban maksimum. Pada saat kondisi awal ditandai dengan keretakan awal pada 
struktur balok sedangkan pada kondisi beban maksimum pola retak terjadi akibat kapasitas beban maksimum telah terlampaui seperti yang diperlihatkan pada Gambar 13. Balok dengan hanya mempunyai tulangan tarik dan balok dengan tulangan tarik dan tulangan tekan, pola retak terbagi menjadi 3 tahap yaitu pola retak pada kondisi awal, pola retak pada saat tulangan leleh, dan pola retak pada kondisi beban maksimum seperti yang diperlihatkan pada Gambar 14-15.

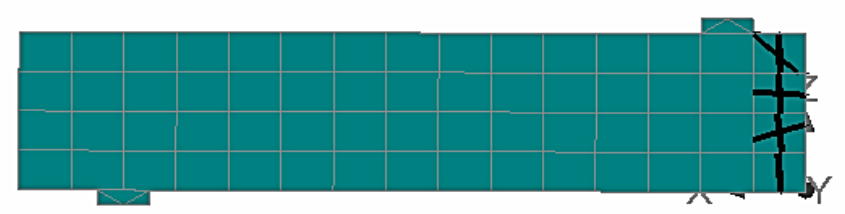

Gambar 13 Pola retak balok tanpa tulangan

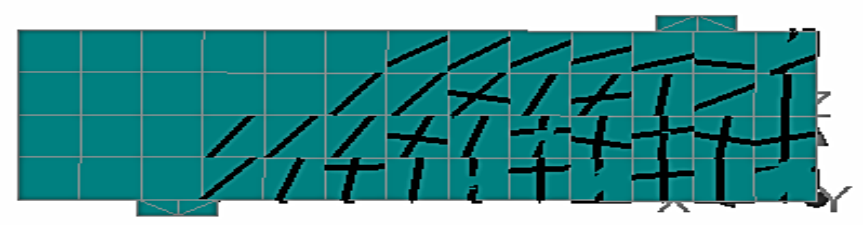

Gambar 14 Pola retak balok dengan tulangan tarik

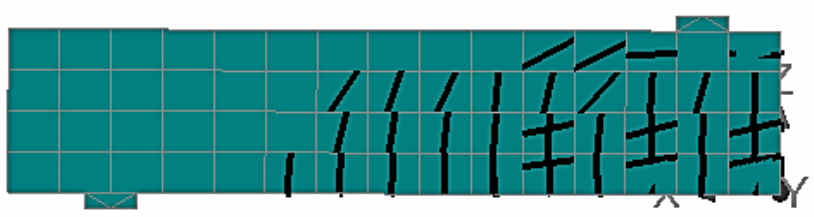

Gambar 15 Pola retak balok dengan tulangan tarik dan tulangan tekan

\section{Kesimpulan}

Berdasarkan hasil analisa pengaruh tulangan tekan pada balok beton bertulang dengan ATENA 3D dapat disimpulkan bahwa:

1. Kapasitas kekuatan balok semakin besar dengan bertambahnya tulangan tarik, tulangan tekan, dan tulangan sengkang. Di sisi lain, dengan bertambahnya panjang balok mulai dari bentang 2 $\mathrm{m}, 3 \mathrm{~m}, 3.5 \mathrm{~m}$, sampai $4 \mathrm{~m}$ mengakibatkan kapasitas kekuatan balok semakin kecil dan dengan bertambahnya mutu beton tidak berpengaruh signifikan pada kapasitas kekuatan dan defleksi pada balok dengan penjang dan properties yang sama

2. Bertambahnya panjang bentang mengakibatkan penurunan kekakuan pada balok bertulang. Di sisi lain, dengan bertambahnya mutu balok mengakibatkan bertambahnya kekakuan pada balok bertulang. Dan juga, dengan penambahan tulangan tekan mengakibatkan bertambahnya kekakuan pada balok bertulang.

3. Bertambahnya panjang bentang mengakibatkan penurunan daktilitas pada balok bertulang. Di sisi lain, dengan bertambahnya mutu balok mengakibatkan berkurang daktilitas pada balok bertulang. Dan juga, dengan penambahan tulangan tekan mengakibatkan penurunan daktilitas pada balok bertulang.

4. Balok dengan hanya mempunyai tulangan tarik dan balok dengan tulangan tarik dan tulangan tekan, pola retak terbagi menjadi 3 tahap yaitu pola retak pada kondisi awal, pola retak pada saat tulangan leleh, dan pola retak pada kondisi beban maksimum 


\section{Daftar Pustaka}

Bastian, E. 2017. Pengaruh Perbandingan Panjang Bentang Geser dan Tinggi Efektif Pada Balok Beton Bertulang. Menara Ilmu, Vol. 11, No. 76, Hal. 55-59, 2528-7613 2528-7613

Cervenka, V., Cervenka, J. \& Pukl, R. 2002. Atena-A tool for engineering analysis of fracture in concrete. Sadhana, Vol. 27, No. 4, Hal. 485-492, 0256-2499 0256-2499

Darma, E. \& Paryati, N. 2019. Investigasi Keruntuhan Geser Balok Tinggi Beton Bertulang dan Beton Fiber Dengan Metode Eksperimental, Metode Numerik dan Metode Strut and Tie. BENTANG: Jurnal Teoritis dan Terapan Bidang Rekayasa Sipil, Vol. 7, No. 2, Hal. 69-78, 2579-3187 2579-3187

Fajarianto, M. F., Zaki, A. \& Thamrin, R., 2020, "Pengaruh Geometri Balok Beton Bertulang Terhadap Perilaku Lentur Menggunakan Program Atena 3D dan RCCSA" dalam Prosiding of 1st UMY Grace 2020 (Bantul, Yogyakarta, 27 October 2020)

Gurdián, H., García-Alcocel, E., Baeza-Brotons, F., Garcés, P. \& Zornoza, E. 2014. Corrosion Behavior of Steel Reinforcement in Concrete with Recycled Aggregates, Fly Ash and Spent Cracking Catalyst. Materials, Vol. 7, No. 4, Hal. 3176-3197, 1996-1944 1996-1944

Mansor, A., Sader Mohammed, A. \& Mansor, M. 2020. Reinforced Concrete Beams Capacity with Various Concrete Compressive Strengths. IOP Conference Series: Materials Science and Engineering, Vol. 978, No. Hal. 012036,

Nawy, E. G. 1998. Beton Bertulang. Suatu Pendekatan Dasar.(Terjemahan), Bandung, PT Refika Aditama, Vol., No. Hal.,

Prayuda, H., Saleh, F. \& Istiawan, I. 2018. Studi Numerik Pengaruh Ukuran Penampang, Rasio Tulangan Lentur dan Jarak Tulangan Geser Terhadap Kekakuan Balok Beton Bertulang Menggunakan Program Respone 2000. Semesta Teknika, Vol. 21, No. 1, Hal. 18-32, 2502$54812502-5481$

Qin, R., Zhou, A. \& Lau, D. 2017. Effect of reinforcement ratio on the flexural performance of hybrid FRP reinforced concrete beams. Composites Part B: Engineering, Vol. 108, No. Hal. 200209, 1359-8368 1359-8368

Renić, T. \& Kišiček, T. 2021. Ductility of Concrete Beams Reinforced with FRP Rebars. Buildings, Vol. 11, No. 9, Hal. 424, 2075-5309 2075-5309

Stefany, S. \& Supartono, F. 2019. Pemodelan Zona Angkur Ganda Dengan Metode Elemen Hingga Dan Strut And Tie Model. JMTS: Jurnal Mitra Teknik Sipil, Vol. 2, No. 1, Hal. 189-198, 2622-545X 2622-545X

Sucharda, O., Brozovsky, J. \& Mikolášek, D. 2014. Numerical modelling and bearing capacity of reinforced concrete beams. Key Engineering Materials, Vol. 577, No. Hal. 281-284, 30378583033037858303

Sukarno, P. \& Sulistyo, D. 2015. Analisis Lentur Balok Penampang T Berlubang Memanjang Menggunakan Metode Elemen Hingga Non-linier. Semesta Teknika, Vol. 14, No. 1, Hal. 1$14,2502-54812502-5481$

Zaki, A. \& Nugroho, A. 2021. Pemodelan Perilaku Beton Berkarat Menggunakan ATENA 3D. Siklus : Jurnal Teknik Sipil, Vol. 7, No. 2, Hal. 175 -186, 